Article

\title{
Efficient Ammonium Removal by Bacteria Rhodopseudomonas Isolated from Natural Landscape Water: China Case Study
}

\author{
Xuejiao Huang, Jiupai Ni, Chong Yang, Mi Feng, Zhenlun Li * and Deti Xie * \\ College of Resources and Environment, Key Laboratory of Soil Multiscale Interface Process and Control, \\ Southwest University, Chongqing 400715, China; hxuejiao0412@sina.com (X.H.); nijiupai@163.com (J.N.); \\ yangchong0412@sina.com (C.Y.); fmfm1996@sina.com (M.F.) \\ * Correspondence: lizhlun4740@sina.com (Z.L.); xdt@swu.edu.cn (D.X.); \\ Tel.: +86-138-8337-2713 (Z.L.); +86-139-0839-4691 (D.X.)
}

Received: 26 July 2018; Accepted: 14 August 2018; Published: 20 August 2018

\begin{abstract}
In this study, we isolated a strain of photosynthetic bacteria from landscape water located in Southwest University, Chongqing, China, and named it Smobiisys501. Smobiisys501 was Rhodopseudomonas sp. according to its cell morphological properties and absorption spectrum analysis of living cells. The analysis of the $16 \mathrm{~S}$ rDNA amplification sequence with specific primers of photosynthetic bacteria showed that the homology between Smobiisys501 and Rhodopseudomonas sp. was $100 \%$, and the alignment results of protein sequences of the bacterial chlorophyll Y subunit showed that Smobiisys501 and Rhodopseudomonas palustris were the most similar, with a similarity of more than $92 \%$. However, Smobiisys501 could not utilize glucose and mannitol as a carbon source and had a low fatty acid content, which were different from the related strains of the genus Rhodopseudomonas. Moreover, the DNA-DNA relatedness was only $42.2 \pm 3.3 \%$ between Smobiisys501 and the closest strain Rhodopseudomonas palustris. Smobiisys501 grew optimally at $30{ }^{\circ} \mathrm{C}$ and $\mathrm{pH}$ 7.0 in the presence of yeast extract, and it could efficiently remove ammonium $(99.67 \%$ removal efficiency) from synthetic ammonium wastewater. All the results indicated that Smobiisys501 was a novel species of Rhodopseudomonas, with the ability to remove ammonium.
\end{abstract}

Keywords: Rhodopseudomonas sp.; anaerobic; characteristics; ammonium

\section{Introduction}

The genus Rhodopseudomonas was first described by Czurda and Maresch [1] and is one of the photosynthetic bacteria (PSB), known as purple nonsulfur bacteria. Up to now, many bacterial strains of Rhodopseudomonas have been reported, isolated from water and mud [2-4]. According to Bergey's Manual of Systematic Bacteriology, the genus Rhodopseudomonas was classified into seven species: Rhodopseudomonas palustris, Rhodopseudomonas marina, Rhodopseudomonas blastica, Rhodopseudomonas sulfoviridis, Rhodopseudomonas rutila, Rhodopseudomonas acidophila, and Rhodopseudomonas viridis [5].

However, delineating species of the genus Rhodopseudomonas is taxonomically challenging due to the poor correlation between phenotypic and genotypic traits, hampering the identification and classification of newly isolated strains [6]. At present, many molecular biological methods including the sequence alignment, G+C content determination, DNA-DNA hybridization, and phospholipid fatty acid analysis have been successfully employed to identify the genus Rhodopseudomonas [2,7,8]. An example of this is PPF2/PPR2, a pair of specific primers designed according to the particular sequence of $16 \mathrm{~S}$ rDNA of Rhodopseudomonas that could accurately identify Rhodopseudomonas [9]. The bchY gene (Y subunit of chlorophyllide oxidoreductase) of anoxygenic photosynthetic bacteria could also distinguish Rhodopseudomonas and anoxygenic photosynthetic bacteria [10]. Therefore, in order 
to classify the new strains more accurately, the phenotypic characteristics and molecular biological characteristics should be used in combination to identify the isolated strains of Rhodopseudomona.

The construction of a landscape waterbody for reshaping the living environment is increasingly popular. However, most landscape water bodies are closed or semi-closed catchments, and the organic nitrogen in them is easily changed to ammonium $\left(\mathrm{NH}_{4}{ }^{+}-\mathrm{N}\right)$. It is notable that excessive ammonium in water can damage the liver and kidney of fish, and make the water stinky. Therefore, removing the undesirable ammonium in landscape water is essential and urgent. Rhodopseudomonas has been used as the most effective bioagent in the field of environmental protection, such as in the treatment of sewage, household, and restaurant wastewater owing to its ability to efficiently remove ammonium [11-14]. However, little research has been conducted on the application of the genus Rhodopseudomonas, even the PSB in the treatment of landscape water ammonium pollution. Furthermore, the pollutant concentration and composition in landscape water are different from life sewage, household, and restaurant wastewater.

In this work, a rod-shaped and red-pigmented strain, named Smobiisys501, was identified by combining the phenotypic characteristics and molecular biological characteristics (including physiological and biochemical characteristics, phospholipid fatty acid (PLFA), DNA-DNA hybridization, $16 \mathrm{~S}$ rDNA sequence, and $b c h Y$ protein sequence analysis). The effects of temperature, $\mathrm{pH}$, and nitrogen source on its growth characteristics were investigated in PSB enrichment medium. Meanwhile, the ammonium removal efficiency of Smobiisys501 from synthetic ammonium wastewater was examined carefully. All the results illustrated that Smobiisys501 was a novel species of Rhodopseudomonas, and it could be used to treat ammonium wastewater because of its high ammonium removal efficiency.

\section{Materials and Methods}

\subsection{Characterization and Identification of the Bacterial Strain}

The water samples for bacterial isolation were taken from the pool of Resources and Environment College, Southwest University, Chongqing, China. The PSB enrichment medium was used to enrich the photosynthetic bacteria, which contained $\left(\mathrm{L}^{-1}\right)$ : $\mathrm{CH}_{3} \mathrm{COONa} 3.3 \mathrm{~g}, \mathrm{NH}_{4} \mathrm{Cl} 0.6 \mathrm{~g}, \mathrm{~K}_{2} \mathrm{HPO}_{4}$ $0.9 \mathrm{~g}, \mathrm{MgSO}_{4} \cdot 7 \mathrm{H}_{2} \mathrm{O} 0.5 \mathrm{~g}, \mathrm{NaHCO}_{3} 0.2 \mathrm{~g}$, and yeast extract $1.5 \mathrm{~g} . \mathrm{CH}_{3} \mathrm{COONa}, \mathrm{NH}_{4} \mathrm{Cl}, \mathrm{K}_{2} \mathrm{HPO}_{4}$, $\mathrm{MgSO}_{4} \cdot 7 \mathrm{H}_{2} \mathrm{O}$, and $\mathrm{NaHCO}_{3}$ are all analytically pure (AR), and yeast extract and agar are biochemical reagents (BR). All the reagents were purchased from new titanium chemical industry in Chongqing. For the preparation of solid plates for isolation and purification, $2 \%(w / v)$ agar was added to the PSB enrichment medium [15]. The collected water $(1 \mathrm{~mL})$ was added to the anaerobic bottle $(1 \mathrm{~L})$ filled with PSB enrichment medium. The bottle was incubated anaerobically in a constant illumination box (light: $2000 \mathrm{~lx}$ ) at $30^{\circ} \mathrm{C}$ for about $7 \mathrm{~d}$. Then, $1 \mathrm{~mL}$ culture was transferred into $1 \mathrm{~L}$ fresh PSB enrichment medium, and the medium was incubated at the same conditions. These works were done three consecutive times until a dark red coloration was achieved [16]. Purification of single colonies was achieved with successive re-streaking in PSB enrichment medium containing 2\% (w/v) agar [17].

Cell morphology of the strain was observed by optical microscopy (Olympus BH-2) and scanning electron microscopy (SEM, JEM-2100F). The physiological and biochemical characteristics of the strain (including carbon source utilization, oxidization $\mathrm{H}_{2} \mathrm{~S}$ test, starch hydrolysis test, et al.) were identified according to related literatures $[18,19]$. Cell pigment scans and absorption spectra of the living cells suspension of the strain were performed using cell pellets resuspended in $60 \%$ sucrose utilizing an Aminco DW-200 UV-Visible spectrometer in the split mode [16].

Genomic DNA of the strain was extracted and purified using a Qiagen genomic DNA extraction kit from Sigma. The specific primers PPF2/PPR2 for photosynthetic bacteria (fwd: $5^{\prime}-$ CTGGAAGTCTTGAGTATGGC-3; rev: 5'-AGTAAACCCACTAACGGCTG-3') [7] and the specific degenerate primers for anaerobic phototrophic bacteria (APB) (fwd: $5^{\prime}$-CCNCARACNATGTGYCCNGC NTTYGG-3'; rev: 5'-GGRTCNRCNGGRAANATYTCNCC-3') [8] were used for the amplification of 
the partial $16 \mathrm{~S}$ rDNA gene and the partial $b c h Y$ gene of the isolates, respectively. PCR products were separated on a $2 \%$ agarose gel and purified by a BioSpin gel extraction kit (BioFlux). The purified product was cloned into the $\mathrm{pMD}^{\circledR} 20-\mathrm{T}$ vector (Takara, Liaoning, China) and then sequenced by Invitrogen Biotechnology Co., Ltd. (Shanghai, China). Then, the sequences were submitted to NCBI for their accession number. Sequence alignment and multiple alignment were performed using the NCBI search tool program (BLAST: https:/ / blast.ncbi.nlm.nih.gov/Blast.cgi) and CLUSTAL W. Additionally, the phylogenetic tree was constructed using MEGA 6.0 software.

DNA-DNA hybridization of the strain was detected by a Perkin Elmer Lambda 35 UV/VIS Spectrophotometer [20]. Levels of DNA-DNA relatedness were determined by triplicate measurements between Smobiisys501 and its closest strain Rhodopseudomonas palustris, reciprocally (mean \pm SD, $n=3$ ). The phospholipid fatty acid (PLFA) composition of Smobiisys501 was analyzed by an Agilent 6850 gas chromatograph (FID detector) after being extracted, saponified, and methylated according to the standard protocol given by the MIDI [21]. The chromatographic conditions were as follows: HP-5 column $(25.0 \mathrm{~m} \times 200 \mu \mathrm{m} \times 0.33 \mu \mathrm{m})$, sample volume was $1 \mu \mathrm{L}$, split ratio was 10:1, the carrier gas $\left(\mathrm{H}_{2}\right)$, tail blowing high purity $\mathrm{N}_{2}$, and used air as auxiliary gas, the velocity was $8 \mathrm{~mL} \cdot \mathrm{min}^{-1}$; the temperature of the vaporization chamber and detector was $250{ }^{\circ} \mathrm{C}$ and $300{ }^{\circ} \mathrm{C}$, respectively. Pre column pressure was $10.0 \mathrm{psi}(1 \mathrm{psi}=6.895 \mathrm{kPa})$, the full scan range of mass spectrometry was 30 to $600 \mathrm{mr} \cdot \mathrm{Z}^{-1}$, and the two-order program column temperature was $170{ }^{\circ} \mathrm{C}(5 \mathrm{~min}) \rightarrow 260^{\circ} \mathrm{C} \rightarrow 310^{\circ} \mathrm{C}$, maintained for $1.5 \mathrm{~min}$. The standard product was purchased from MIDI Company (New York, NY, USA), and the C19:0 was used as an internal standard to convert the absolute content of PLFA.

\subsection{Effect of Culture Conditions on Bacterial Growth Characteristics}

In order to obtain the optimal growth conditions of Smobiisys501, three cultivation conditions which affect the growth of Smobiisys501 including temperature (10, 20, 30, 35, 40, 45, and $50{ }^{\circ} \mathrm{C}$ ), $\mathrm{pH}\left(4,5,6,7,8,9\right.$, and 10), and nitrogen source (nitrate $\left(\mathrm{LiNO}_{3}, \mathrm{NaNO}_{3}, \mathrm{KNO}_{3}\right)$, ammonium $\left.\left(\mathrm{CH}_{3} \mathrm{COONH}_{4}, \mathrm{NH}_{4} \mathrm{Cl},\left(\mathrm{NH}_{4}\right)_{2} \mathrm{C}_{2} \mathrm{O}_{4}\right),\left(\mathrm{NH}_{4}\right)_{2} \mathrm{SO}_{4}\right)$, organic nitrogen (urea, peptone, and yeast extract)) were determined [22]. The $\mathrm{pH}$ value of raw water was adjusted to desirable values using $0.1 \mathrm{M}$ $\mathrm{NaOH}$ or $0.1 \mathrm{M} \mathrm{HCl}$. Smobiisys501 was activated on PSB solid plates, and then a single colony of Smobiisys501 was inoculated into $100 \mathrm{~mL}$ PSB enrichment medium cultured at $30{ }^{\circ} \mathrm{C}$ for $7 \mathrm{~d}$. In total, $1 \mathrm{~mL}$ of pre-cultured Smobiisys501 was centrifuged at $4000 \mathrm{r} \cdot \mathrm{min}^{-1}$ for $8 \mathrm{~min}$ and washed twice with sterilized pure water before being inoculated into a $250 \mathrm{~mL}$ anaerobic bottle full of PSB enrichment medium $\left(\mathrm{OD}_{600}=0.3\right.$, different nitrogen sources were used to replace $\mathrm{NH}_{4} \mathrm{Cl}$ in PSB enrichment medium when explored the effect of nitrogen source on growth of Smobiisys501). Furthermore, the anaerobic bottles were incubated in a constant illumination box (light: $2000 \mathrm{~lx}$ ) at $30^{\circ} \mathrm{C}$ for $48 \mathrm{~h}$. Then, the $\mathrm{OD}_{600}$ values were determined using a spectrophotometer (UV1000, Techcomp Limited, Shanghai, China) at the wavelength of $600 \mathrm{~nm}$. All experiments were conducted in triplicate.

\subsection{Application of Smobiisys501 to Ammonium Removal}

Synthetic ammonium wastewater (contained ( $\mathrm{L}^{-1}$ ): $\mathrm{CH}_{3} \mathrm{COONa} 0.34 \mathrm{~g}, \mathrm{NH}_{4} \mathrm{Cl} 0.02 \mathrm{~g}, \mathrm{~K}_{2} \mathrm{HPO}_{4} 0.09 \mathrm{~g}$, $\mathrm{MgSO}_{4} \cdot 7 \mathrm{H}_{2} \mathrm{O} 0.05 \mathrm{~g}, \mathrm{NaHCO}_{3} 0.34 \mathrm{~g}$ ) was used to investigate the ammonium removal efficiency of Smobiisys501. Smobiisys501 was incubated on PSB solid plates, and then a single colony of Smobiisys501 was inoculated into $100 \mathrm{~mL}$ PSB enrichment medium cultured at $30{ }^{\circ} \mathrm{C}$ for $7 \mathrm{~d}$. Different concentrations of pre-cultured Smobiisys501 were centrifuged at $4000 \mathrm{r} \cdot \mathrm{min}^{-1}$ for $8 \mathrm{~min}$ and washed twice with sterilized pure water before being inoculated into a $250 \mathrm{~mL}$ anaerobic bottle $(0.5 \mathrm{~mL}$ : 0.2\% inoculums of Smobiisys501 isolate; $1 \mathrm{~mL}: 0.4 \%$ inoculums of Smobiisys501 isolate; $1.5 \mathrm{~mL}: 0.6 \%$ inoculums of Smobiisys501 isolate) which was filled with synthetic ammonium wastewater. Moreover, synthetic ammonium wastewater without inoculation was used as the control (CK). All experiments were conducted in triplicate. The cultures were incubated at the optimal $\mathrm{pH}$ and temperature. Additionally, the concentration of ammonium in water was measured every $3 \mathrm{~d}$ using the indophenol blue method at room temperature [23]. The ammonium removal efficiency was calculated by the 
equation: $R v=(T 1-T 2) / T 1 \times 100 \%$ to assess the ammonium removal ability of Smobiisys 501 . Note that $R v, T 1$, and $T 2$ represent the ammonium removal efficiency, the initial concentration of ammonium, and the final concentration of ammonium in water after incubation, respectively.

\subsection{Statistical Analysis and Graphical Work}

Statistical analysis and graphical work were carried out using Excel, SPSS Statistics, and Origin8.6. The results were presented as means \pm SD (standard deviation of means).

\section{Results and Discussion}

\subsection{Characterization of Smobiisys501}

\subsubsection{Morphological and Absorption Spectra Characteristics}

Smobiisys501 was found to grow well under the light of the anaerobic condition, but could not to grow under a dark and anaerobic condition. Colony morphologies of Smobiisys501 were red-brown, convex, and circular, with a diameter of 1.2-1.5 mm when it grew on the solid plates of PSB enrichment medium after incubation at $30{ }^{\circ} \mathrm{C}$ for $7 \mathrm{~d}$. The cells were spherical on acid medium (Figure 1a), and long rods on alkaline medium (Figure $1 b$ ) under an optical microscope. The microscopic scanning test of the Smobiisys501 utilizing SEM clearly showed that the single cell of Smobiisys501 was budding and the size of a single bacterial cell was about $0.6-0.8 \mathrm{~mm}$ wide and $1.2-1.5 \mathrm{~mm}$ long (Figure 1c). Additionally, the double staining test of the isolate showed that the isolate was a Gram-negative species. The absorption spectra of the living cells showed characteristic absorption peaks at 375 , $490,520,805$, and $870 \mathrm{~nm}$, indicating the presence of bacteriochlorophyll a and carotenoids of the spheroidene series [24,25]. These are characteristic features of a photo bacterium, which illustrated that Smobiisys501 is a typical PSB, and might be Rhodopseudomonas sp.
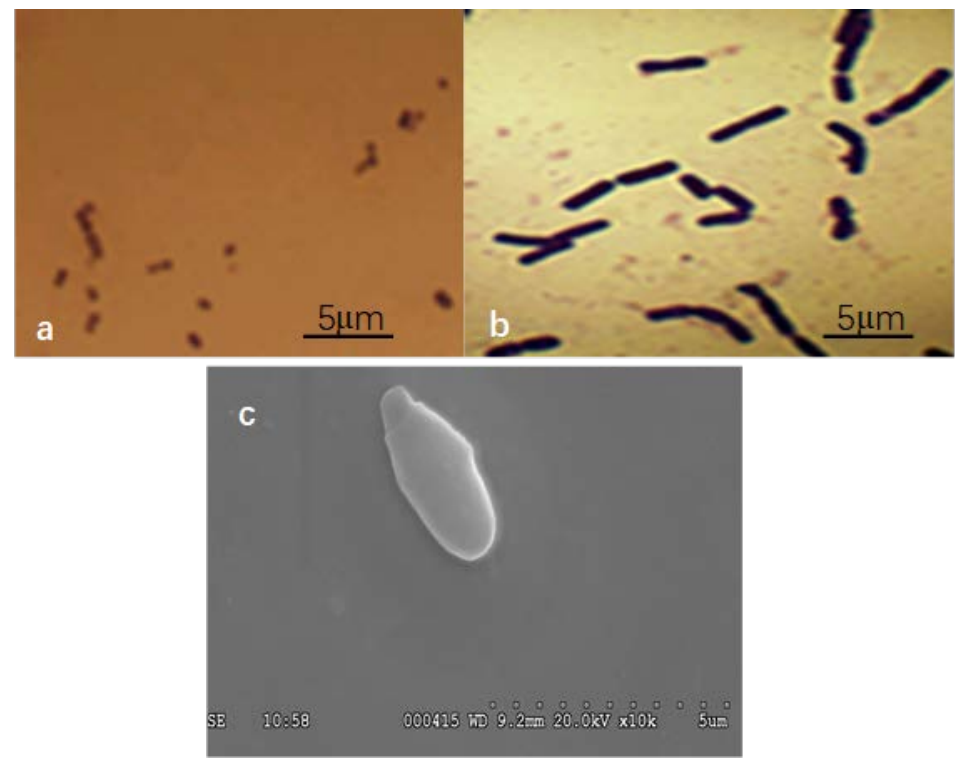

Figure 1. The morphology of Smobiisys501 under a microscope. (a): Cell morphology of Smobiisys501 under an optical microscope $(10 \times 100)$ in acid medium $(\mathrm{pH}=6)$; (b): Cell morphology of Smobiisys501 under an optical microscope $(10 \times 100)$ in alkaline medium $(\mathrm{pH}=9)$; (c): Cell morphology of Smobiisys501 under an electron microscope $(2000 \times 10)$.

\subsubsection{Phylogenetic Analysis}

According to sequence similarity calculations of the 16S rDNA gene, Smobiisys501 was most closely related to Rhodopseudomonas sp. (AB696784, 99\%), Rhodobacter sphaeroides (HM053959, 
99\%), Rhodopseudomonas faecalis (HQ154127, 99\%), Rhodopseudomonas palustris (KJ722766, 99\%), and Rhodopseudomonas thermotolerans (NR108528, 99\%). The 16S rDNA-based phylogenetic tree constructed using the neighbor-joining method showed the same result, where Smobiisys501 was placed in a cluster within the genera Rhodopseudomonas (Figure 2). The results strongly supported the species-level classification of Smobiisys501 within the genus Rhodopseudomonas.

The 507bp BchY gene was transformed into a 168 aa protein sequence. Phylogenetic analysis based on the bch $Y$ protein sequence indicated that Smobiisys501 was most closely related to Rhodopseudomonas palustris (ALB25898, 100\%), Rhodopseudomonas palustris (WP027279534, 95\%), Rhodopseudomonas palustris (WP011662766, 92\%), Rhodopseudomonas sp. AAP120 (WP054165526, 89\%), and Rhodopseudomonas sp. B29 (WP022723271, 88\%). The bchY-based phylogenetic tree depicting the phylogenetic relationships of Smobiisys501 with the related strains using the neighbor-joining method is shown in Figure 3, where Smobiisys501 was most adjacent to Rhodopseudomonas palustris. The phylogenetic result based on the bchY protein was consistent with those based on the $16 \mathrm{~S}$ rDNA gene, suggesting that Smobiisys501 belonged to the genus Rhodopseudomonas, and might be Rhodopseudomonas palustris.
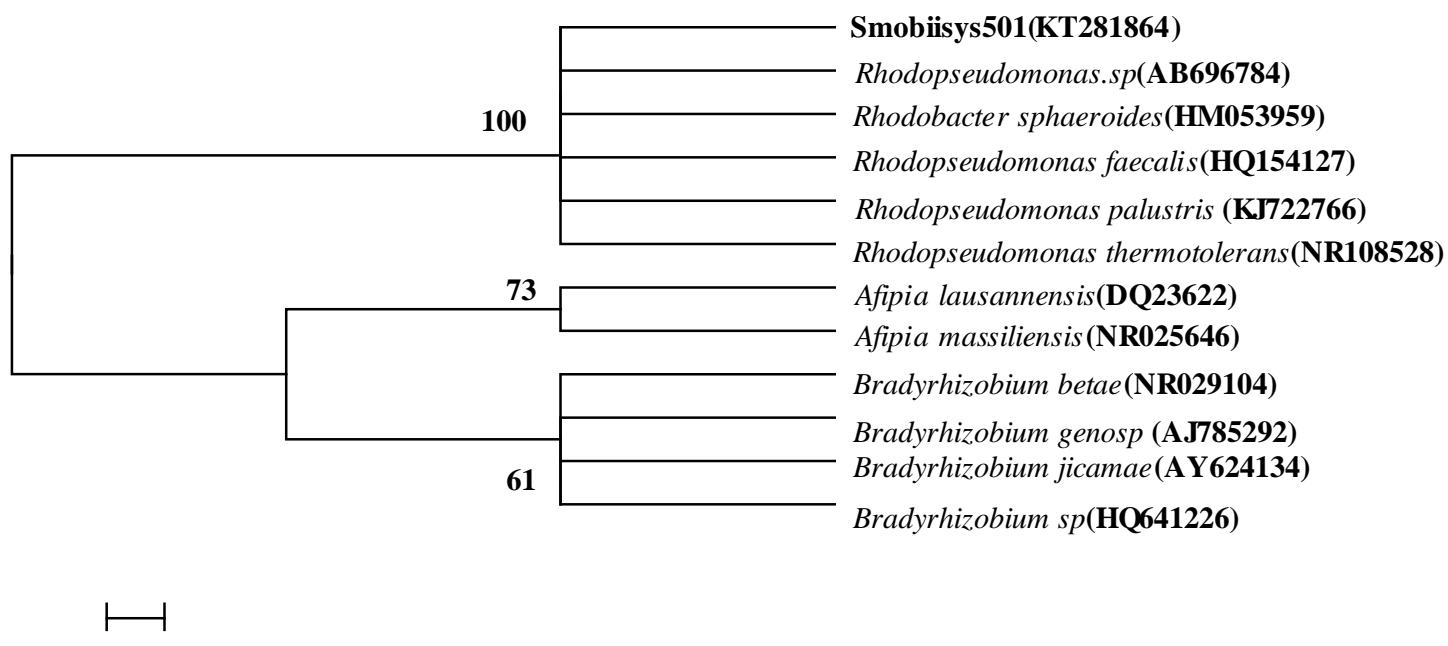

0.5

Figure 2. Phylogenetic tree of Smobiisys501 based on the 16S rDNA gene homology.

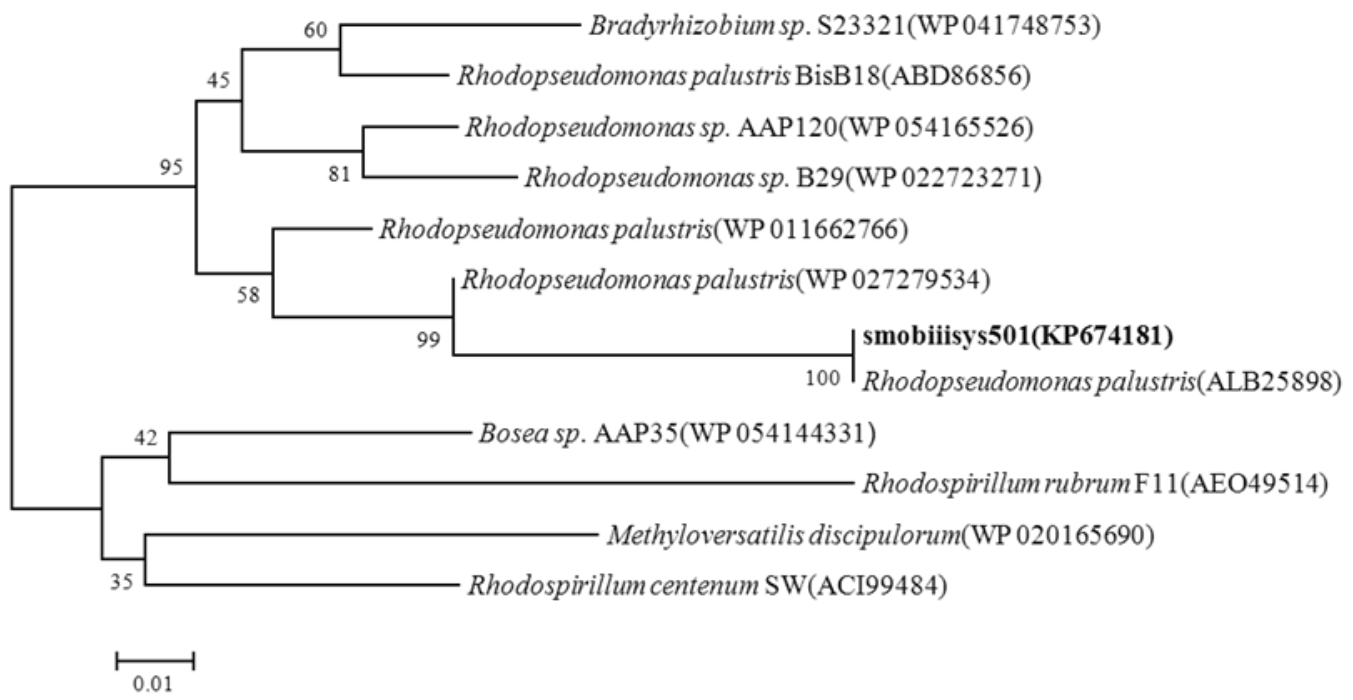

Figure 3. Phylogenetic tree of the strain Smobiisys501 based on the BchY protein homology. 


\subsubsection{Physiological-Biochemical Characteristics}

Smobiisys501 was a Gram-negative bacterium, which contained oxidase and catalase and was positive for the production of indole, and it could also utilize sodium acetate. However, it was negative for the oxidization of $\mathrm{H}_{2} \mathrm{~S}$ and starch hydrolysis, and it did not have the ability to utilize methanol, glucose, sodium thiosulfate, and mannitol (Table 1). Previous research found that Rhodopseudomonas faecalis, Rhodopseudomonas palustris, and Rhodobacter sphaeroides (which were most adjacent to Smobiisys501) had the ability to utilize glucose and mannitol, demonstrating that there were some differences in the utilization of carbon sources between Smobiisys501 and the three type species of Rhodopseudomonas sp. [26,27].

Table 1. The physiological and biochemical characters of Smobiisys501.

\begin{tabular}{cccc}
\hline \multicolumn{2}{l}{ Physiological Characteristics } & \multicolumn{2}{c}{ Biochemical Characteristics } \\
\hline Carbon source utilization & + & Oxidase & + \\
Sodium acetate & + & Catalase & + \\
methanol & - & Indole & + \\
glucose & - & Oxidization $\mathrm{H}_{2} \mathrm{~S}$ & - \\
Sodium thiosulfate & - & Starch hydrolysis & - \\
Mannitol & - & Gram stain & - \\
\hline
\end{tabular}

\subsubsection{DNA-DNA Hybridization}

Normally, when strains share a similarity of more than $97 \%$ in the $16 \mathrm{~S}$ rDNA gene sequence identity, the DNA-DNA hybridization technique has been especially successful in resolving taxonomic relationships at the species level and below [28]. In this study, the closest strain Rhodopseudomonas palustris was selected for DNA-DNA hybridization with Smobiisys501. The value of genomic DNA relatedness as shown by the DNA-DNA hybridization was only $42.2 \%$, which was well below the $70 \%$ threshold proposed for species delineation [29].

\subsubsection{Cellular Fatty Acid Analysis}

A total of more than ten kinds of fatty acids of Smobiisys501 were detected, and the proportion of $\mathrm{C}_{18: 1 \omega 7 \mathrm{c}}$ was the highest, which could reach $38.43 \%$. Smobiisys 501 showed a similar major fatty acid composition to the related type strains of the genus Rhodopseudomonas (Table 2), but there were significant quantitative differences when cultivated under the same conditions by comparing it with the three adjacent strains in the phylogenetic trees [26,27], which indicated that Smobiisys501 was different from the other three strains.

Table 2. Cellular fatty acid profiles (\%) of Smobiisys501 and closely related species of the genus Rhodopseudomonas.

\begin{tabular}{ccccc}
\hline Fatty Acid Composition (\%) & $\mathbf{1}$ & $\mathbf{2}$ & $\mathbf{3}$ & $\mathbf{4}$ \\
\hline $\mathrm{C}_{12: 0}$ & 3.05 & 1.6 & - & 1.7 \\
$\mathrm{C}_{16: 0}$ & 19.13 & 20.8 & 5.1 & 14.9 \\
$\mathrm{C}_{16: 1 \omega 7 \mathrm{c} / 16: 1 \omega 6 \mathrm{c}}$ & 19.29 & 10.2 & 1.9 & 6.2 \\
$\mathrm{C}_{18: 1 \omega 7 \mathrm{c}}$ & 38.43 & 51 & 77.2 & 63 \\
\hline
\end{tabular}

1 represents Smobiisys501; 2 represents Rhodopseudomonas palustris ATCC 17001T; 3 represents Rhodobacter sphaeroides DSM158T; 4 represents Rhodopseudomonas faecalis JCM $11668 \mathrm{~T}$.

Morphological and absorption spectra analysis showed that the main characteristics of Smobiisys501 were consistent with the characteristics of the genus Rhodopseudomonas. The alignment result of the 16S rDNA amplification sequence with specific primers of photosynthetic bacteria (PPF2/PPR2) showed that the homology between Smobiisys501 and Rhodopseudomonas sp. was 100\%, 
and the alignment results of protein sequences of the bacterial chlorophyll $Y$ subunit showed that Smobiisys501 and Rhodopseudomonas palustris were the most similar, with a similarity of more than 92\%. However, the physiological and biochemical characteristics, the main fatty acid analysis, and the DNA-DNA hybridization found that there were obvious differences between Smobiisys501 and the related strains of the genus Rhodopseudomonas. For instance, Smobiisys501 could not utilize glucose and mannitol as a carbon source and had a lower fatty acid content. Furthermore, the DNA-DNA relatedness was only $42.2 \pm 3.3 \%$ between Smobiisys501 and the closest strain Rhodopseudomonas palustris. These differences indicated that Smobiisys501 might be a new member of the genus Rhodopseudomonas.

\subsection{Effects of Culture Conditions on the Growth of Smobiisys501}

The effect of temperature, $\mathrm{pH}$, and nitrogen sources on the growth of Smobiisys501 is shown in Figure 4 . Within the temperature range of $10-50{ }^{\circ} \mathrm{C}$, Smobiisys501 grew better at higher temperatures, but when the temperature reached $35^{\circ} \mathrm{C}$, bacterial growth decreased. The optimal growth temperature of Smobiisys501 was about $30^{\circ} \mathrm{C}$ (Figure 4a), which was consistent with the reported strain of the genus Rhodopseudomonas [30]. In this study, the growth of Smobiisys501 was affected by the $\mathrm{pH}$, like in previous studies [31,32]. The optimal $\mathrm{pH}$ was 7 with $\mathrm{OD}_{600}$ values of 0.53 after anaerobic incubation for $48 \mathrm{~h}$ (Figure 4b). At pH 6.0-9.0, Smobiisys501 grew better. However, it could not grow at $\mathrm{pH} 4$ $\left(\mathrm{OD}_{600}=0.01\right)$ and $\mathrm{pH} 10\left(\mathrm{OD}_{600}=0.01\right)$. These findings also indicated that Smobiisys501 has a wide adaptability to the $\mathrm{pH}$ in water, and it could survive in weak acidic and weak alkaline environments. The result was consistent with the reported strain of the genus Rhodopseudomonas [33]. As shown in Figure $4 \mathrm{c},\left(\mathrm{NH}_{4}\right)_{2} \mathrm{SO}_{4}, \mathrm{NaNO}_{3}$, and yeast extract were the most suitable ammonium nitrogen, nitrate nitrogen, and organic nitrogen for the growth of Smobiisys501, respectively. Interestingly, yeast extract could dramatically stimulate the growth of the strain compared to other nitrogen sources. This might because the yeast extract contains organic carbon sources which will accelerate the biomass growth. However, $\mathrm{CH}_{3} \mathrm{COONH}_{4},\left(\mathrm{NH}_{4}\right)_{2} \mathrm{C}_{2} \mathrm{O}_{4}$, urea, and peptone could not noticeably sustain the growth of strain, although they also contain organic carbon sources. The results implied that containing organic carbon was not the main factor which meant that the yeast extract could significantly promote the growth of the strain. Further analysis is needed for specific reasons. On the basis of the study above, yeast extract was found to be the optimal nitrogen source for strain growth.

\subsection{Assessment of Ammonium Removal by Smobiisys501}

Research has shown that the excess of ammonium is one of the main causes of eutrophication. Therefore, reducing the content of ammonium will be an effective means to control the eutrophication of a water body [34]. The purpose of this experiment was to investigate the effect of inoculation on $\mathrm{NH}_{4}{ }^{+}-\mathrm{N}$ removal efficiency while the water initial $\mathrm{pH}$ value and temperature were controlled at 7 and $30{ }^{\circ} \mathrm{C}$, respectively. The concentration of $\mathrm{NH}_{4}{ }^{+}-\mathrm{N}$ was significantly decreased in $3 \mathrm{~d}$ after being treated by Smobiisys501 in comparison with the control (Figure 5). While there was a different ammonium removal efficiency among three inoculation quantity treatments, the higher the inoculation quantity, the better the ammonium removal efficiency. The optimum inoculation quantity of Smobiisys501 was $0.4 \%$ when taking into account the medicament cost and ammonium removal efficiency, and under this condition, the ammonium removal efficiency reached $99.67 \%$. These results showed that Smobiisys501 has the ability to effectively remove ammonium in wastewater, and could be used for the governance of ammonium polluted water. Moreover, $\mathrm{NO}_{2}-\mathrm{N}$ and $\mathrm{NO}_{3}-\mathrm{N}$ were nearly undetectable during the experiments, which indicated that Smobiisys501 could reduce the ammonium in water under an anaerobic condition owing to assimilation [35] rather than dissimilation. 

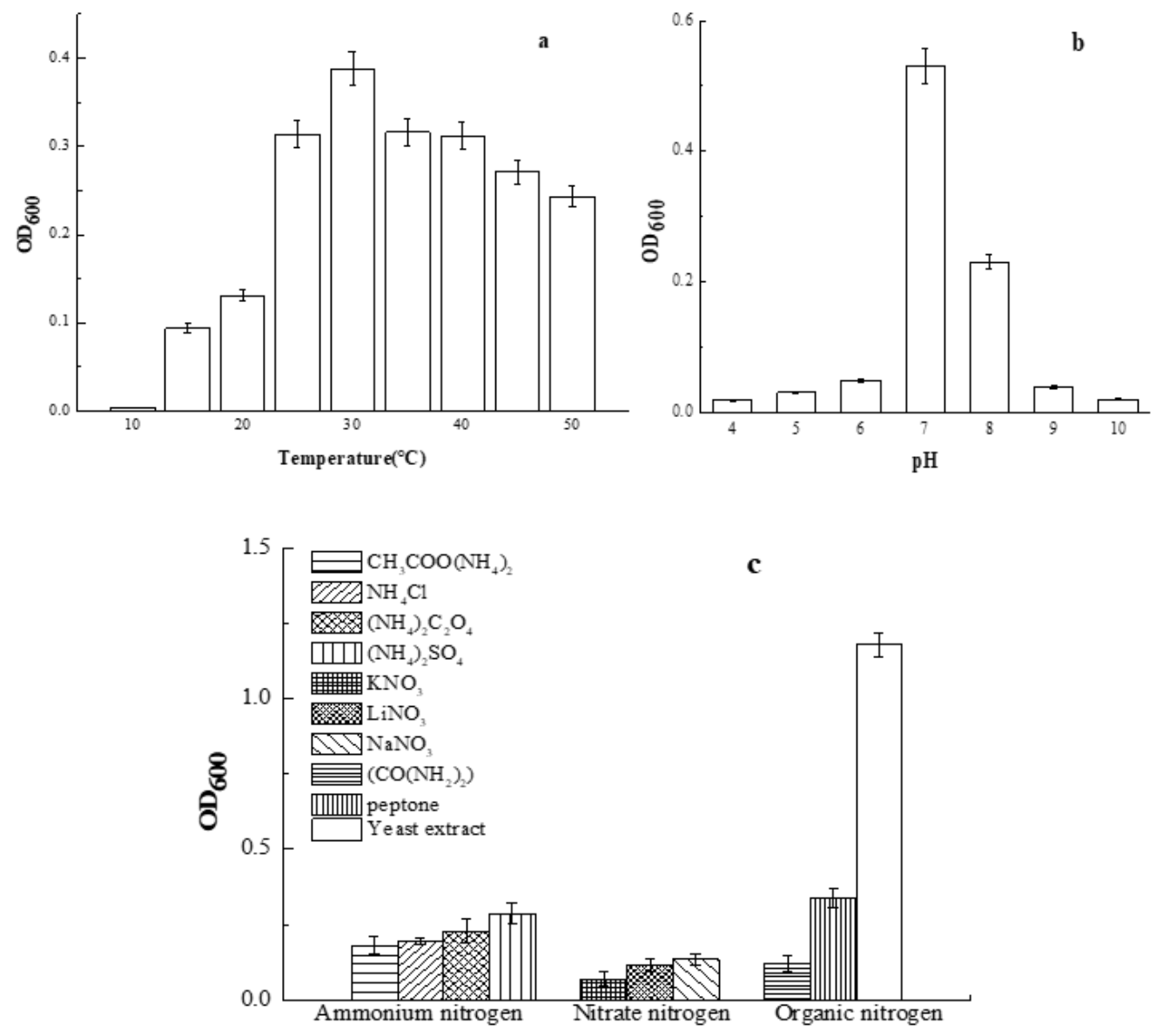

Figure 4. Effect of culture conditions on the growth of Smobiisys501. (a) represents the effect of temperature; (b) represents the effect of $\mathrm{pH}$; (c) represents the effect of nitrogen sources.

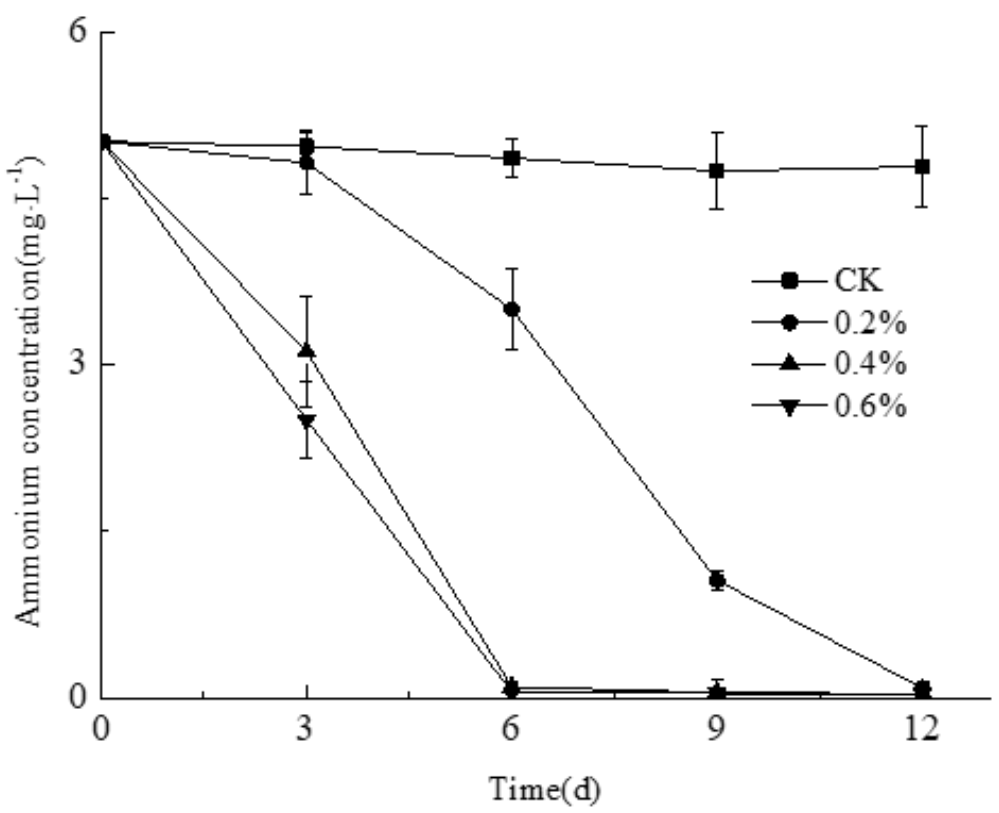

Figure 5. Variation of $\mathrm{NH}_{4}{ }^{+}$with time in synthetic ammonium wastewater treated by Smobiisys501. 


\section{Conclusions}

This study reports a new member of the genus Rhodopseudomonas, named Smobiisys501, as an anaerobic bacterium. Smobiisys501 belongs to the genus Rhodopseudomonas according to the morphological and absorption spectra analysis, as well as the alignment result of the $16 \mathrm{~S}$ rDNA amplification sequence with specific primers of photosynthetic bacteria. The alignment result of protein sequences of the bacterial chlorophyll Y subunit showed that Smobiisys501 might be Rhodopseudomonas palustris because they exhibited the highest similarity (similarity of more than $92 \%$ ). But there was a great difference in the biological properties of Smobiisys501 and Rhodopseudomonas palustris according to physiological biochemical characteristics, the main fatty acid analysis, and the DNA-DNA hybridization. These differences indicated that Smobiisys501 was a novel species of Rhodopseudomonas. Smobiisys 501 grew optimally at $30^{\circ} \mathrm{C}$ and pH 7.0 in the presence of yeast extract. In addition, Smobiisys 501 exhibits the highest ammonium removal ability at $30{ }^{\circ} \mathrm{C}$ and $\mathrm{pH}$ 7.0, where the ammonium removal efficiency was up to $99.67 \%$. Accordingly, Smobiisys501 can be potentially used for removing ammonium in landscape water.

Author Contributions: X.H. and C.Y. conceived and designed the experiments; X.H., C.Y., and M.F. carried out the experiments; X.H., C.Y., M.F., and Z.L. analyzed the data; X.H., Z.L., J.N., and D.X. wrote the main manuscript text and all authors reviewed the manuscript.

Funding: This research was funded by Fundamental Research Funds for the Central Universities (XDJK2018D030), the National Natural Science Fund (41671291), and the National Key Research and Developmental Program of China (2017YFC0404705)

Acknowledgments: We thank associate professor Chengsheng $\mathrm{Ni}$ for his linguistic assistance during the preparation of this manuscript.

Conflicts of Interest: The authors declare no conflict of interest.

\section{References}

1. Czurda, V.; Maresch, E. Beitrag zur Kenntnis der Athiorhodobakterien-Gesellschaften. Arch. Mikrobiol. 1937, 8, 99-124. [CrossRef]

2. Wei, H.; Okunishi, S.; Yoshikawa, T.; Kamei, Y.; Maeda, H. Isolation and characterization of a purple non-sulfur photosynthetic bacterium Rhodopseudomonas faecalis strain a from swine sewage wastewater. Biocontrol Sci. 2016, 21, 29-36. [CrossRef] [PubMed]

3. Hiraishi, A.; Okamura, K. Rhodopseudomonas telluris sp. nov., a phototrophic alphaproteobacterium isolated from paddy soil. Int. J. Syst. Evol. Microbiol. 2017, 67, 3369-3374. [CrossRef] [PubMed]

4. Liu, B.F.; Jin, Y.R.; Cui, Q.F.; Xie, G.J.; Wu, Y.N.; Ren, N.Q. Photo-fermentation hydrogen production by Rhodopseudomonas sp. nov. strain A7 isolated from the sludge in a bioreactor. Int. J. Hydrog. Energy 2015, 40, 8661-8668. [CrossRef]

5. Imhoff, J.F.; Trüper, H.G.; Pfennig, N. Rearrangement of the species and genera of the phototrophic "purple nonsulfur bacteria". Int. J. Syst. Evol. Microbiol. 1984, 34, 340-343. [CrossRef]

6. Okamura, K.; Takata, K.; Hiraishi, A. Intrageneric relationships of members of the genus Rhodopseudomonas. J. Gen. Appl. Microbiol. 2009, 55, 469-478. [CrossRef] [PubMed]

7. Kumar, B.V.; Ramprasad, E.V.V.; Sasikala, C.; Ramana, C.V. Rhodopseudomonas pentothenatexigens sp. nov. and Rhodopseudomonas thermotolerans sp. nov., isolated from paddy soils. Int. J. Syst. Evol. Microbiol. 2013, 63, 200-207. [CrossRef] [PubMed]

8. Phankhamla, P.; Sawaengkaew, J.; Buasri, P.; Mahakhan, P. Biohydrogen production by a novel thermotolerant photosynthetic bacterium Rhodopseudomonas pentothenatexigens strain KKU-SN1/1. Int. J. Hydrog. Energy 2014, 39, 15424-15432. [CrossRef]

9. Guan, D.W.; Li, J.; Shen, D.L.; Cao, F.M.; Li, L. Construction and application of photosynthetic bacteria PCR detection technology. Chin. J. Appl. Environ. Biol. 2008, 14, 699-704.

10. Yutin, N.; Suzuki, M.T.; Rosenberg, M.; Rotem, D.; Madigan, M.T.; Süling, J.; Imhoff, J.F.; Béjà, O. BchY-based degenerate primers target all types of anoxygenic photosynthetic bacteria in a single PCR. Int. J. Syst. Evol. Microbiol. 2009, 75, 7556-7559. [CrossRef] [PubMed] 
11. Zhang, X.P.; Shu, M.A.; Wang, Y.B.; Fu, L.Q.; Li, W.F.; Deng, B.; Liang, Q.; Shen, W.Y. Effect of photosynthetic bacteria on water quality and microbiota in grass carp culture. World J. Microbiol. Biotechnol. 2014, 30, 2523-2531. [CrossRef] [PubMed]

12. Hülsen, T.; Batstone, D.J.; Keller, J. Phototrophic bacteria for nutrient recovery from domestic wastewater. Water Res. 2014, 50, 18-26. [CrossRef] [PubMed]

13. Meng, F.; Yang, A.; Wang, H.; Zhang, G.; Li, X.; Zhang, Y.; Zou, Z. One-step treatment and resource recovery of high-concentration non-toxic organic wastewater by photosynthetic bacteria. Bioresour. Technol. 2018, 251, 121-127. [CrossRef] [PubMed]

14. Talaiekhozani, A.; Rezania, S. Application of photosynthetic bacteria for removal of heavy metals, macro-pollutants and dye from wastewater: A review. J. Water Process Eng. 2017, 19, 312-321. [CrossRef]

15. Huang, X.J.; Yang, C.; Ni, J.P.; Li, Z.L. Isolation, identification and characteristics of a Rhodopseudomonas with high ammonia-nitrogen removal efficiency. Environ. Sci. 2016, 37, 2276-2283.

16. Madukasi, E.I.; Chunhua, H.; Zhang, G. Isolation and application of a wild strain photosynthetic bacterium to environmental waste management. Int. J. Environ. Sci. Technol. 2011, 8, 513-522. [CrossRef]

17. Lakshmi, K.V.N.S.; Sasikala, C.; Ramana, C.V. Rhodoplanes pokkaliisoli sp. Nov., a phototrophic alphaproteobacterium isolated from a waterlogged brackish paddy soil. Int. J. Syst. Evol. Microbiol. 2009, 59, 2153-2157. [CrossRef] [PubMed]

18. Hot, G.J.; Krieg, R.N.; Sneath, H.A.P. Bergey's Manual of Determinative Bacteriology; Baltirnore: Washington, DC, USA, 1994.

19. Dong, Z.X.; Cai, M.Y. Handbook of Common Bacterial System Identification; Thomson Learning Press: Beijing, China, 2001.

20. Ley, J.; Cattoir, H.; Reynaerts, A. The quantitative measurement of DNA hybridization from renaturation rates. Eur. J. Biochem. 1970, 12, 133-142. [CrossRef] [PubMed]

21. Huang, X.; Shi, W.; Ni, J.; Li, Z.L. Evaluation of laboratory-scale in situ capping sediments with purple parent rock to control the eutrophication. Environ. Sci. Pollut. Res. 2017, 24, 7114-7123. [CrossRef] [PubMed]

22. Romanenko, L.A.; Tanaka, N.; Svetashev, V.I. Devosia submarina sp. nov., isolated from deep sea surface sediments. Int. J. Syst. Evol. Microbiol. 2013, 63, 3079-3085. [CrossRef] [PubMed]

23. State Environmental Protection Administration. Methods for Monitoring and Analysis of Water and Wastewater; Chinese Environmental Science Press: Beijing, China, 2012.

24. Hiraishi, A.; Muramatsu, K.; Urata, K. Characterization of new denitrifying Rhodobacter strainsisolated from photosynthetic sludge for wastewater treatment. J. Ferment. Bioeng. 1995, 79, 39-44. [CrossRef]

25. Madigan, M.T.; Jung, D.O.; Woese, C.R.; Achenbach, L.A. Rhodoferax antarcticus sp. nov., a moderately psychrophilic purple nonsulfur bacterium isolated from an antarctic microbial mat. Arch. Microbiol. 2000, 173, 269-277. [CrossRef] [PubMed]

26. Girija, K.; Sasikala, C.; Ramana, C.V.; Spröer, C.; Takaichi, S.; Thiel, V.; Imhoff, J.F. Rhodobacter johrii sp. nov., an endospore-producing cryptic species isolated from semi-arid tropical soils. Int. J. Syst. Evol. Microbiol. 2010, 60, 2099-2107. [CrossRef] [PubMed]

27. Ramana, V.V.; Chakravarthy, S.K.; Raj, P.S.; Kumar, B.V.; Shobha, E.; Ramaprasad, E.V.V.; Sasikala, C.; Ramana, C.V. Descriptions of Rhodopseudomonas parapalustris sp. nov., Rhodopseudomonas harwoodiae sp. nov. and Rhodopseudomonas pseudopalustris sp. nov., and emended description of Rhodopseudomonas palustris. Int. J. Syst. Evol. Microbiol. 2012, 62, 1790-1798. [CrossRef] [PubMed]

28. Tindall, B.J.; Rossello-Mora, R.; Busse, H.J.; Ludwig, W.; Kämpfer, P. Notes on the characterization of prokaryote strains for taxonomic purposes. Int. J. Syst. Evol. Microbiol. 2010, 60, 249-266. [CrossRef] [PubMed]

29. Wayne, L.G.; Brenner, D.J.; Colwell, R.R.; Grimont, P.A.D.; Kandler, O.; Krichevsky, M.I.; Moore, H.; Moore, W.E.C.; Murray, R.G.E.; Stackebrandt, E.; et al. Report of the ad hoc committee on reconciliation of approaches to bacterial systematics. Int. J. Syst. Evol. Microbiol. 1987, 37, 463-464. [CrossRef]

30. Arunasri, K.; Ramana, V.V.; Spröer, C.; Sasikala, C.; Ramana, C.V. Rhodobacter megalophilus sp. nov., a phototroph from the Indian Himalayas possessing a wide temperature range for growth. Int. J. Syst. Evol. Microbiol. 2008, 58, 1792-1796. [CrossRef] [PubMed]

31. Cao, W.P.; Zhang, Y.Q. Removal of nitrogen (N) from hypereutrophic waters by ecological floating beds (EFBs) with various substrates. Ecol. Eng. 2014, 62, 148-152. [CrossRef] 
32. Liang, Z.; Liu, Y.; Ge, F.; Wong, M. A pH-dependent enhancement effect of co-cultured Bacillus licheniformis on nutrient removal by Chlorella vulgaris. Ecol. Eng. 2015, 75, 258-263. [CrossRef]

33. Chen, H.; Zhang, D.M.; Wang, L.G.; Pan, Z. Biological characteristics and phylogenetic analysis of a denitrifying photosynthetic bacterium. Acta Microbiol. Sin. 2011, 51, $249-255$.

34. Zhou, Q.; Zhang, G.; Zheng, X.; Liu, G. Biological treatment of high $\mathrm{NH}_{4}{ }^{+}-\mathrm{N}$ wastewater using an ammonia-tolerant photosynthetic bacteria strain (ISASWR2014). Chin. J. Chem. Eng. 2015, 23, 1712-1715. [CrossRef]

35. Takabatake, H.; Suzuki, K.; Ko, I.B.; Noike, T. Characteristics of anaerobic ammonia removal by a mixed culture of hydrogen producing photosynthetic bacteria. Bioresour. Technol. 2004, 95, 151-158. [CrossRef] [PubMed]

(C) 2018 by the authors. Licensee MDPI, Basel, Switzerland. This article is an open access article distributed under the terms and conditions of the Creative Commons Attribution (CC BY) license (http:/ / creativecommons.org/licenses/by/4.0/). 